\title{
ГЛАСНИК
}

АДВОКА Т КЕ КОМОРЕ ВО ВОДИНЕ ЧАСОПИС 3 П ПАВНУ ТЕОРИЈУ И ПРАКСУ

Година LXVIII

Новн Сад, април 1996

Књига 56

Број 4

\section{Ч ЛАНЦИ}

Др Борислав Кайамација

професор Медицинског факултета у Новом Саду, у пензији

Др Гордана Мищић-Павков

асистент Медицинског факултета у Новом Саду

\section{ПОТРЕС МОЗГА - КРИВИЧНОПРАВНИ И ГРАЋАНСКОПРАВНИ ЗНАЧАЈ *}

\begin{abstract}
САЖЕТАК: Аүтори ухазују на проблеме у класификацији церебралних повреда. Основни проблем је днјагностиширати лаку повреду главе и правиги јасну разлику измеБу ове и тешке повреде мозга. Повреде мозга се деле у две групе: потрес мозга и контузија, што представља грубу поделу. Постоје многи случајеви који не могу бити класифнковани на овај начнн, тј. тешке повреде могуһе је да имају неке елементе контүзије мозга које се не могу открити уобичајеним дијагностичким методама. Посебну пажњу обратили су на стања измењене свести: бесвесно стање и стање помућене свести, које имају огроман форензички значај. Овај рад обухвата такоbе и све форензичке аспекте кривнчног и грађанског права.

Кзучне речи: повреда мозга, сүдска медицина.
\end{abstract}

Први писани подаци о повреди главе и мозга потичу још из старог Египта и садржани су у хијероглифском запису познатом под именом „Edwin Smith” папирус. Медицина старе Грчке допуњава знања из ове области у обимном делу „Corpus Hippocraticum”, а фран-

* Рад примъен: 15. I 1996. 
цуски хирург Петит у 18. веку поставља дијагностнчке критеријуме комоције (потреса) и контузије (нагњечења) мозга. Поред дуге историје медицинске мисли још увек су бројне недоумице и контроверзе везане, како за форензички, тако и за медицински аспект траума главе и мозга. Као прво, и данас се поставља питање која се повреда главе може сматрати и кранноцеребралном траумом односно и повредом мозга. Jennett и Teasdale $(1974 ; 1977)$ сматрају да је свака повреда главе и краниоцеребрална траума. Тешке трауме са озбиљним поремећајем стања свести и неуролошким дефицитом не представљају дилему у било ком смислу. Проблем се јавља код малих повреда код којих је днскутабилно да ли је уопште дошло до трауме мозга, познате као потрес мозга (commotio cerebri). Питање дијагностичких критеријума ове повреде и данас је отворено, а спор у односу на последище исте трауме далеко је од решења и присутна су два опречна става која „без остатка” деле истражнваче у овој области.

У подручју номенклатуре и класификације не постоји једннствена терминологија. Општепознати и у класичним уцбенищима навоЊени термини комоција и контузија мозга у потпуности су изгубили своје значење и практично се не употребљавају у савременој литератури која третира ову проблематику. Сигурно да је један од најозбиљнијих разлога огроман „јаз" измеbу ове две категорије трауматских оштећења мозга, односно непостојање „прелазних" облика. Англосаксонска литература уводи термин „brain concussion” који покрива врло широку лепезу повреда у односу на њихову тежину. Потрес (комоција) мозга означава се као ,slight concussion of the brain" (лаки потрес мозга). Као клинички критеријуми за дијагностику наводе се краткотрајан, изненадан и трауматски изазван поремећај мождане функције који укључује бесвесно стање и/или амнезију без спољних знакова оштећења можданог ткива (Verjaal и van T Hooft, 1975). Сама дефиниција намеће нека питања, пре свега везана за врсту и трајање поремећаја свести. Губитак свести обично траје неколико минута и за тај период постоји амнезија (несећање). Већина аутора се слаже да губитак свести не мора да постоји. Fischer (1966) сматра да код умерених и тешких потреса мозга систем будности н меморије бивају погоБени у исто време, али они нису једнако вулнерабилни, по правилу будност је мање осетљива и она се прва поново успоставља. Капамаџија $(1982 ; 1989)$ истиче огроман форензички значај управо оних церебралних траума, по правилу потреса мозга, код којих се накнадно, најчешће приликом судскопсихијатријске експлорације у циљу вештачења, добија податак о амнезијн, а да при томе у медицинској документацији нема трага о губитку свести. Аутор сматра да се велики број оваквих случајева може објаснити стањима помућћене свести која „измичу” дијагностици чак и од стране лекара непсихијатара.

За разлику од потреса мозга где, у моменту повреБивања, долази до бруталног нарушавања можданих функција, али и до рапидног и потпуног опоравка ad integrum, контузија мозга је клинички синдром 
који представља локализовану или дифузну анатомску лезију мозга (Нагулић, 1975). Као клинички ентитет, церебрална контузија се карактерише присуством патоанатомског супстрата, лезијом мозга и неуролошким дефицитом. Обзиром на ширину појма контузије, јасно је да се комоција и контузија меБусобно преклапају и да је најчешће немогуће начинити јасну дистинкцију измеbу потреса мозга и лаке контузије. У складу са тим Ерцеговац (1976) наводи да се све чешће у клиничком раду користи подела церебралних траума на две основне групе: комошионо-контузиони и компресивни синдром. У земљама енглеског говорног подручја уместо термина контузија користи се "moderate" или severe concussion" (умерен или јак потрес). Да појмовни галиматијас буде очуван Verjaal и van T Hooft (1975) наглашавају да се термин контузија (а не moderate или severe brain concussion) користи за случајеве „тешког concussion синдрома са значајним лацерацијама ткива". Наведени термини - комоција и контузија мозга користи се у клиннчком раду и то су углавном дијагнозе са којима се среће вештак, најчешће психијатар.

Постоји могућност превазилажења постојећих проблема. Наиме, јасно је да је „чист” потрес мозга изузетно ретка појава, да велики број блажих контузија бива неднјагностикован или сврстан у групу потреса, да се стања свести дијагностикују само када постоји губитак свести, а да помућења свести, по правилу, остају неевидентирана. Амнезија као касни и трајни дефицит меморије мора се узети у обзир, јер она постоји као индикатор измењеног стања свести (губитка и/или помућења) у време трауме. Управо на темељу посттрауматске амнезије као једног од најконстантнијих пратилаца церебралне трауме, предложена је нова подела тежине церебралне трауме и ова подела се користи у апсолутно свим савременим истраживањима. Захваљујући снажном развоју неуропсихологије, посттрауматска амнезија је постала мерљив клинички ентитет и на основу неуропсихолошке евалуацнје могућа је суптилна процена, не занемарујући при том „класичне” методе днјагностике (неуролошки преглед, лумбална пункија, компјутеризована томографија) као и савремене методе: нуклеарна магнетна резонанца и метода евоцираних потенцијала. Јасно је да неуропсихолошка процена трајања посттрауматске амнезије захтева перманентно праћење пацијента, а ово подразумева хоспиталне услове (поред обученог кадра - психолога субспецијалисте, односно неуропсихолога). Такоbе све друге наведене дијагностичке процедуре везане су за постојање одреБене (обично скупе) медипинске опреме, обученог кадра и подразумевају да буду обављене само уз одреБене индикације за ту врсту претраге (нпр. клинички утисак комоције мозга не подразумева ниједну од наведених дијагностика). Према томе, врло је мало изгледа да се у свакодневном клиничком раду превазиБу постојеће тешкоће. У научноистраживачким пројектима обезбеБују се услови које савремена схватања захтевају и резултати оваквих истраживања нам помажу да мање грешимо у практичном раду, који he се још дуги низ годнна 
заснивати на актуелној дијагностици и свим проблемима који из ње произилазе.

Посебан, пре свега форензички проблем, јесте пнтање постојања касних психолошко-психнјатријских последища церебралне трауме. Јасне, клинички манифестне и дијагностиковане контузије мозга не представљају проблем ни код вештачења. Постојање касних секвела и могућност њихове објективизације на клиничком и психолошком плану нису спорни. Проблем представьају лаке церебралне трауме, а појава такозваног посткомоционог синдрома је честа и као таква налази се у свнм досадашњим пскхнјатријским класификацијама па н у најновијој ICD-10. Посткомоциони синдром (синонимн: субјективни синдром након повреде главе, посттрауматски снндром, postconcussional syndome, encephalopathia posttraumatica) cе може одредити као констелација симптома који су константни и стереотигни и који се јавьају након мннималне, благе или тешке трауме главе и мозга (Турдију, 1990). Посебно су непомирљиви ставови аутора у погледу етиологије овог снндрома. Једни заговарају органско порекло симттома, сматрајући да је оно добро документовано низом неуропатолошких, неурофизиолошких н неуропсихолошких студија. Други су искључнви у тврБењу да су тегобе које следе, посебно након лакше трауме, психогене природе и у први план истичу значај личности и рентних тенденција. Levin (1989) износи помирљив став тврдећ̆и да симптоми посттрауматског синдрома почињу на органској, а перзнстирају на пскхнчкој основи.

У односу на учесталост појаве, Long и Novac (1986) наводе да $80 \%$ особа са претрпљеном церебралном траумом, без обзира на степен њене тежине, спонтано наводе тегобе из оквира посттрауматског синдрома, а циљаном евалуацијом тај број се повећава на $90 \%$ и нсти аутори сматрају да универзалност симптома упућује на њихово заједничко порекло. Ни питање временског трајања тегоба није решено. Савремена истраживања говоре о трајним, пре свега когнитивним дефицитима, чак и након лаке церебралне трауме (Мишић-Павков, 1995). Evans (1992) сматра да су манифестације посткомоционог синдрома уобичајене у трајању од три до шест месеци после повреде, али перзистентни симптоми могу да трају још месецима, па чак и годинама. Као ризнчне факторе у односу на појаву трајних тегоба наводи: животну доб преко 40 година, нижи образовни интелектуални и социјални ниво, припадност женском полу, конзумирање алкохола, раннје повреде главе и политрауму. Evans сматра да је значај симулације и рентних неуроза у објашњењу посткомоционог синдрома од мапог значаја.

Трајне последице церебралне трауме могу се сврстати у две велике групе: когнитивни дефицит и поремећај емоција, личности и са њима повезаним аспектима понашања (Hinkeldey и Corrigan, 1990).

Код благих можданих траума већина истражнвања показује да се когннтивни дефниит консолидује унутар 6 месеци после повреде (Mc Flynn и сар., 1984). Далеко је днскутабилније пнтање поремећаја 
емоција и личности, а управо промене у овој сфери најзначајнији су разлог соџијалне дисфункионалности које су честе код особа које су претрпеле церебралну трауму. У односу на вештачење касних последища церебралне трауме психијатар-форензичар, у крајњој инстанщи, није оптерећен питањима етиологије и бројним теоријским контроверзама. Наиме, психопатолошке секвеле када постоје, код свих степена тежине мождане трауме резултују променама на плану личности и понашања, односно ремете сферу интерперсоналних релација и доприносе промени у сопственом доживљају себе и својих вредности као и свеукупном променом социјалног функционисања. Једино у том смислу је могуће вршити форензичку процену менталних последица церебралне трауме: шта траума значи за особу, колико мења њен квалитет живота и умањује доживљај животне радости. Према томе, сваки случај захтева посебну процену, јер клинички истоветне повреде, преламајући се кроз призму личности, добијају у психолошком смнслу сасвим различита значења.

\section{КРИВИЧНОПРАВНИ ЗНАЧАЈ}

У кривичном праву односно у судннци потрес мозга има двојаку важност:

1. треба, путем вештака, квалификовати тежину повреде код оштећеног и

2. треба проценити утицај на понашање оптуженог после повреде главе и потреса мозга.

У односу на квалификацију повреде, ствар је доста компликована јер медицинска литература није баш сасвим сагласна с тим шгто у последње време преовлаБује мишљење да је потрес мозга лака телесна повреда. Такав став сагласно заузимају и Институт за судску медицину Медицинског факултета у Новом Саду и Институт за неурологију, психијатрију и ментално здравље у Новом Саду. На први поглед би то све било јасно, али ннје. Разлог је врло једноставан: права природа и тежина повреде се могу утврдити и проценнти тек при протоку времена од најмање годину дана! Да ли је то био „чист” потрес мозга нли је у питању била мања или већ̆ контузија, не може се одмах знати. Шта то значи за кривично право, јасно је. Кривичноправни поступак би морао бити заустављен на најмање годину дана док се буде могло констатовати о чему се заправо ради. То је, наравно, незамисливо. То још није све: ако се наһе вештак који још припада „старинском" медицинском ставу да је потрес мозга тешка телесна повреда, онда је хаотично стање неминовно. Наравно, ако се ради о ситуацијама где се на основу клиничке и евентуално друге медицинске дијагностичке претраге може одреБеније рећи да се ради о контузији мозга - онда ствар и неће бити тако компликована. Наиме, контузија мозга је, као што је већ речено, тешка телесна повреда, јер је у тим случајевима структурно оштећено мождано 
ткиво. Штавише, контузија мозга може да захвати тако велико подручје можданог ткива да то може да изазове и смрт, али, у најмању руку, трајне последице. У односу на исход код контузије треба увек мислити на могућ̆ност ннтракранијалног и/или интрацеребралног крварења и могућности развоја компресије мозга што, у највећем броју случајева, без правовремене дијагностике и хируршке интервенщије има леталан исход.

Код бројних случајева убиства, убиства у покушају или тешких телесних повреда, оптужени је у тучи био повреБен и у пределу главе. Треба знати да се никада не може и не сме рећи да ударац није изазвао потрес мозга и следствену ошамућеност. „Вештаци су установили да оптужени није претрпео потрес мозга..." (како су то установили?) или „Овакав ударац није могао изазвати потрес мозга...". Овакви налази звуче гротескно и у сваком случају би их требало одбацити. Но, шта прихватити? То је врло деликатан посао који само вештак стручњак за судску психнјатрију сме и може да преузме, а увек са ризиком и да погреши. Само што ће број његових грешака бити далеко мањи него када то раде вештаци других струка. Тако, на пример, није свеједно да ли је оптужени пуцао непосредно после задобијања сигурно доказаних удараца по глави или је пуцао неколико минута после тога. Још бројне факторе вештак мора да узме у обзир и анализира индивидуално у сваком појединачном случају. Треба знати и то да тврдња која се још понегде може наћи у старим уџбеницима да потрес мозга изазива губитак свести не стоји и превазиБена је. Да би се све то лакше разумело, мислимо да је најцелисходније упоредити то са оним што се догаБа боксерима на рингу: ударац (или ударци!) у главу може да изазове губитак свести, али може да изазове и ошамућеност („гроги”). Један наш познати боксер је, у своје време, после једног меча у коме је победио, изјавио да се после једног ударца у главу задобијеног од стране противника, ничег више не сећ̆а, иако је до краја меча прописно боксовао и решио меч у своју корист. Слична стања се, не ретко, догађају и у ситуацијама туча или где је оптужени из других разлога (саобраћајни удес, на пример) био ошамућен (стручно кажемо: помућене свести) и онда извршио неко кривично дело.

\section{ГРАБАНСКОПРАВНИ ЗНАЧАЈ}

Проблематика овде има сличности, али и разпка у односу на до сада речено. У предметима неимовинске штете потрес мозга и повреда главе (стручно: краниоцеребралне повреде) има врло велики значај и представља деликатан посао.

Пре свега, проблематично је питање ране дијагностике ових повреда. Главни је проблем што се одмах после трауматизације (најчешће после саобраћајног удеса, али и туча или повреда на раду) пропусти да се установи право стање. Хирург-трауматолог, коме по- 
вреьени прво долази "У руке”, гледа шта је хитно „да закрпи", тј. крварења, преломе итд. Какво је стање свести, на то се најчешhе не обраһ̆а пажња, јер то није од виталне важности, уосталом лекари непсихијатри нису ни вични оваквој дијагностици. За њих постоје два стања: или је при свести или није при свести. Tertius non datur. Управо ово треће је најважније, а то су стања помућене свести која су у таквим ситуацијама најчешиа. Треба искрено рейи да чак ни психијатар, ако није посветио довољно времена и пажње и своје дијагностичке напоре усмерио у том правцу, не мора таква стања увек да региструје. Но, психијатар се најчешће у таквим ситуацијама и не зове као консултант, јер то што је болесник евентуално збуњен и "говори мало без везе" није од виталног значаја и има времена да се и после види шта је. После се можда уопште и не позове консултант пскхијатар, а онда се, не ретко, праве грубе грешке, па се на отпусној листи као коначна дијагноза стави (поред остапнх дијагноза или сама за себе) commotio cerebri (потрес мозга). Меbутим, из исторнја боловања се може видети да је болесник-повреьени бно две-три недеље везан због психомоторног немира, да је имао делимнчну одузетост једне стране, или одузетост живаца покретача очних јабучица, дакле озбиљан неуролошки налаз, што код „чнстог” потреса мозга, ако тако нешто уопште и постоји, не долази у обзир.

Ако сада све ово узмемо у обзир, онда је јасно са каквом лошом стартном основом почиње вештачење касних последица краниоцеребралних повреда. Јер, ако се није одмах честито цијагностиковало и регистровало, како онда накнадно ца утврБујемо? Пре свега, цела судскопсихијатријска литература је сагласна да од повреде па до предузимања оваквих вештачења треба да проБе најмање годину дана, а чини се да је већина оних који заговарају и две и три године! Треба се кратко осврнути на захтев неких осигуравајућих завода да се као основ за неимовинску штету могу узимати само „болнички утврђени потреси мозга”. Такву бесмислицу је могао смислити само неко ко нема појма о овој материји и њеној проблематици. То је врло лепо рекао Вау (Беј): „... још никада нисмо видели да је чист потрес мозга донесен на клинику без свести". Другим речима: ако је донесен без свести, онда то није потрес мозга, него компликованија ситуација.

Изоставићемо овде детаљније изношење технике и методике вештачења касних последица краниоцеребралних повреда, јер би то захтевало мало више простора. Напомињемо само да чврсто стојимо на томе да је за оваква вештачења, по нашем мншљењу, компетентан само вештак специјалиста за судску психијатрију уз асистенцију психолога који својим минуциозним трагањем за органским пснхичким променама пружа незаобилазну помоћ психијатру.

На крају, и после најстручније и најминуциозније изведеног испитивања, врло често вештаку не преостаје друго него да коначно мишљење даје „по слободној процени вештака". Јасно је да је то врло непрецизно, али када бисмо имали времена и простора да овде 
изложимо шта ми ипак дијагностички предузимамо (то је већ чисто медищински посао) видело би се да и није баш тако непрецизно како се на први поглед чини. Ако то ради довољно стручан и искусан вештак, онда ће утолико бити и мање грешака.

\section{PE3HME}

Аутори расправљају о актуелним проблемима у области дијагностике, номенклатуре и класификације краниоцеребралних траума. Централно место, са аспекта форензичке психијатрије има потрес мозга или commotio cerebri обзиром на проблеме дијагностике (најчешће ретроградно постављање дијагнозе) као и посебно проблематичну процену стања свести - губитак или помућење свести са консекутивном амнезијом. Посебан је проблем немогућности јасне дистинкције измеБу комоцнје и контузије мозга, односно чешће него што се то у пракси уважава постојање комбиноване комоционо-контузионе повреде што, опет, има бројне импликације на вештачење. Питање касних последица церебралних траума огромно је и спорно подручје како у области научног истраживања тако и у клиничкој и форензичкој пракси. Покушавајући да дају интегрални аспект краниоцеребралних траума, аутори са посебном пажњом истичу оне моменте који су кључни у односу на кривичноправни и грађанскоправни значај, тј. судскопсихијатријски аспект ове проблематнке.

\section{ЛITTEPATYPA}

1. Ерцеговац, Н. (1976). Трауме главе и мозга. У: Костић, С. (Ед), Хирургија централног нервног система (pp. 465-503), Београд-Загреб. Медицинска књига.

2. Evans, R. W. (1992). The postconcussional syndrome and sequelae of mild head injury. Neurol. Clin., 10, 815-847.

3. Hinkeldey, N. S., Corrigan, J. D. (1990). The structure of head-injured patients neurobehavioural complaints: a preliminary study. Brain Injury, 4, 115-133.

4. Jennett, B. (1972). Late effects of head injuries. In: Critchley, M., O. Leary, J. L., Jenneth, B. (Eds.), Scientific foundations of neurology (pp. 441-451). London. W. Heinemann Medical Books.

5. Jennett, B., Teasdale, G. (1977). Aspects of coma after severe head injury. Lancet, 1, 878-881.

6. Fischer, C. M. (1966). Concussion amnesia. Neurology, 16, 826-830.

7. Капамашија, Б. (1982). Форензички проблеми ране днјагностике кранноцеребралних повреда и поремећаја свестн. Медицински преглед, 3-4, 93-95.

8. Капамаџија, Б. (1989). Форензичка психијатрија. Београд-Загреб. Медицинска књига.

9. Levin, H. S. (1989). Memory deficit after closed-head injury. J. Neurol. Neurosurg. Psychiatry, $12,129-153$.

10. Long, C. J., Novac, T. A. (1986). Postconcussion symptoms after head trauma: Interpretation and treatment. Southern Medical Joumal, 79, 728-732. 
11. Mc Flynn, G., Montgomery, E. A., Fenton, G. W., Rutherford, W. (1984). Measurement of reaction time following minor head injury. J. Neurol. Neurosurg. Psychiatry, 47, 1326-1331.

12. Мипиһ-Павков, Г. (1995). Касне псканјатријске последице комоцноно-контузионе церебралне трауме - форензичка проблематика. Докторска днсертација, Медицински факултет, Нови Сад,

13. Нагулић, И. (1975). Неурохирургија. Београд, Институт за стручно усавршавање и специјалнзацију здравствених радника.

14. Түрдиу, Ј. (1990). Клничка неуропсихологија. Загреб. Школска књига.

15. Verjaal, A, van T Hooft, F. (1975). Commotio and contusio cerebri (cerebral concussion). In: Vinken, P. J., Bruyn, G. W. (Eds.), Handbook of clinical neurology (pp. 417-442). Amsterdam. North-Holland Publ.

\section{COMMOTIO CEREBRI - FORENSIC ASPECTS \\ Borislav Kapamadžija-Gordana Mišic-Pavkov}

\section{Summary}

Authors emphasize the existence of many problems in classification of cerebral injuries. The basic problem is to diagnose mild head injury and setting the clear distinction between it and severe brain injury. Dividing brain injuries in only two groups: commotio cerebri and contusio cerebri is too rough. There are many cases that cannot be clasified in that manner i.e. severe commotio probably has some elements of contusio cerebri that are undetectable when usual diagnostic methods are applied. The special attention was paid to the states of modified consciousness: unconsciousness and the state of dizziness, which has the enormous forensic importance. This paper covers also all the forensic aspects of criminal and civil law.

Key words: brain injury, forensic medicine. 